\title{
Artificial induction of lactation in cattle
}

\section{Priscila Ribeiro Corradi Freitas ${ }^{1}$, Sandra Gesteira Coelho ${ }^{2}$, Euler Rabelo ${ }^{3}$, Ângela Maria Quintão Lana ${ }^{2}$, Maria Alexandra Torres Artunduaga ${ }^{4}$, Helton Mattana Saturnino ${ }^{2}$}

\author{
1 Programa de Pós graduação em Zootecnia UFMG, Belo Horizonte, MG, Brasil. \\ 2 Departamento de Zootecnia - UFMG - Belo Horizonte, MG, Brasil. \\ ${ }^{3}$ ReHagro - Belo Horizonte, MG, Brasil. \\ ${ }^{4}$ Facultad de Ciencias Agropecuarias Universidad de La Salle - Bogotá, Colombia.
}

ABSTRACT - Forty Holstein cows, with previous reproductive problems, empty, at second or more lactations, with an average milk production of $9,200 \mathrm{~kg}$ in the previous lactation and a dry period over than 50 days were distruibuted in two groups to evaluate two protocols of milking induction. It was given to group 1, on days one, eight and 21 recombinant bovine somatotropin-bSTr $(500 \mathrm{mg})$; from day two to eight, estradiol cypionate $(0.075 \mathrm{mg} / \mathrm{kg} \mathrm{BW})$ and medroxi progesterone acetate $(0.25 \mathrm{mg} / \mathrm{kg} \mathrm{BW})$; from days nine to 15 , estradiol cypionate $(0.037 \mathrm{mg} / \mathrm{kg} \mathrm{BW})$; on day 19 , prostaglandin F2 $\alpha(0.530 \mathrm{mg})$ and from days 19 to 21 , isoflupredone acetate $(0.05 \mathrm{mg} / \mathrm{kg} \mathrm{BW})$. Group two was given, on days one, eight and 21, bSTr (500 mg), from days 2 to 15 , estradiol benzoate $(0.071 \mathrm{mg} / \mathrm{kg} \mathrm{BW})$, from days two to eight, acetate of medroxi progesterone $(0.25 \mathrm{mg} / \mathrm{kg} \mathrm{BW})$, day 19, prostaglandin F2 $\alpha(0.530 \mathrm{mg})$ and from days 19 to 21 isoflupredone acetate, $(0.05 \mathrm{mg} / \mathrm{kg} \mathrm{BW})$. Teats and udders of all cows were massaged for five minutes from day 17 to 21 . Milking were carried out from the $22^{\text {nd }}$ day of induction. After beginning of lactation, both groups were given bsTr (500 mg) every 14 days. It was used a complete random design with 20 replicates per treatment and a split-plot scheme. Evaluation of the protocols was carried out by using analyses of variance using Fisher's test at 5\% and production of milking per day using regression analyses. Milking was successfully induced in $85 \%$ of the animals. Animals from group 2 showed production mean $21.9 \pm 12.9 \mathrm{~kg}$ of milk/day which was higher than group 1 mean $18.9 \pm 11.5 \mathrm{~kg}$ of milk/day. There was no difference for milk composition in either groups. Twenty-nine cows were inseminated and $41.1 \%$ became pregnant.

Key Words: estradiol benzoate, estradiol cypionate, milk production, somatotropin

\section{Indução artificial de lactação em bovinos}

\begin{abstract}
RESUMO - Quarenta vacas holandesas, com problemas reprodutivos prévios, vazias, de segunda ou mais lactações, com produção média de $9.200 \mathrm{~kg}$ na lactação anterior, e período seco superior a 50 dias foram distribuídas em dois grupos para avaliar dois protocolos de indução da lactação. O grupo 1 recebeu nos dias um, oito e 21 somatotropina bovina recombinante - bSTr (500 mg); nos dias dois a oito cipionato de estradiol $(0,075 \mathrm{mg} / \mathrm{kg} \mathrm{PV})$ e acetato de medroxi progesterona $(0,25 \mathrm{mg} / \mathrm{kg} \mathrm{PV})$, do dia nove ao 15 cipionato de estradiol (0,037 mg/kg PV); no dia 19 prostaglandina F2 $\alpha$ (0,530 mg) e dias 19 a 21 acetato de isoflupredona (0,05 mg/kg PV). O grupo 2 recebeu, nos dias um, oito e $21 \mathrm{bSTr}$ (500 mg), nos dias dois a 15 benzoato de estradiol (0,071 mg/kg PV), do dia dois ao oito acetato de medroxi progesterona (0,25 mg/kg PV), no dia 19 prostaglandina F2 $\alpha$ (0,530 mg), e dias 19 a 21 acetato de isoflupredona $(0,05 \mathrm{mg} / \mathrm{kg} \mathrm{PV})$. Todos os animais tiveram o úbere e tetos massageados do dia 17 a 21 por cinco minutos. As ordenhas foram realizadas a partir do 22 o dia da indução. Após o início da lactação, os dois grupos receberam bSTr (500 mg) a cada 14 dias. Utilizou-se delineamento inteiramente ao acaso, com 20 repetições por tratamento e arranjo em parcelas subdivididas. A avaliação dos protocolos foi realizada por análise de variância utilizando-se o teste de Fisher a 5\% e a produção por dia de lactação por análise de regressão. A lactação foi induzida com sucesso em $85 \%$ dos animais. Os animais do grupo 2 apresentaram média de produção de 21,9 \pm 12,9 kg leite/dia sendo superior a média do grupo 1 de 18,9 $\pm 11,5 \mathrm{~kg}$ leite/dia. Não houve diferença quanto à composição do leite nos dois grupos. Vinte e nove vacas foram inseminadas, destas $41,1 \%$ ficaram gestantes.
\end{abstract}

Palavras-chave: benzoato de estradiol, cipionato de estradiol, produção de leite, somatotropina 


\section{Introduction}

In dairy herds, reproductive failure seems to be one of the main causes for involuntary culling, which leads to productive and economic losses once such failures reduce the number of milking cows and, as a consequence, affects milk production/ha/year. A retrospective study in Brazil from 2000 to 2003, using data from 2,083 dairy cows of six dairy herds showed that reproductive failures were responsible for $27.7 \%$ of culling rates (Silva, 2004).

One measure that could have been taken, in order to decrease the involuntary culling rate, is achievement of maximal reproductive efficiency, although it is not easy to get to it because reproductive traits are characterized for having low repeatability and so it will be affected by several factors. Accordingly, artificial induction of lactation is one of the tools that the producer count with to reduce the involuntary culling rate as well as the genetic losses.

During the last three decades, induction of lactation protocols have been used with estradiol benzoate and progesterone. Smith \& Schanbacher (1973) showed that lactation could be induced into treating cows for seven days with $17 \beta$ - estradiol (1 mg/kg BW) and progesterone $(0.25 \mathrm{mg} / \mathrm{kg} \mathrm{BW})$. The purpose was to induce the high steroids concentrations observed during the last month of gestation when a high mammary development occurs. Following studies increased the treatment period from seven to eleven or twelve days, although they neither showed better induction of lactation rates nor elimination of the milk production variation in cows artificially induced (Jewell, 2002).

Collier et al. (1977) used reserpine injections on days 8, 10, 11 and 12 of the artificial induction lactation protocol with estrogen and progesterone. Reserpine was used in order to hassle a prolactin release and its use decreased the variation in milk production amongst animals as well as it showed an increase in the induction of lactation rate. Magliaro et al. (2004) evaluated the efficiency of bSTr in the increase in milk production in dairy cows artificially induced with estrogen and progesterone and observed that bSTr treated cows produced $21.9 \%$ more milk when compared to induced cows that did not receive bSTr.

Mellado et al. (2006) increased estradiol and progesterone doses as well as the protocol length, which was 21 days. The protocol included doses of estrogen, progesterone, flumethasone, prostaglandin and bSTr.

The main purpose of this study was to evaluate the performance of dairy cows regarding to milk production and composition and treated with two artificial induction protocols without resperin use and different estrogen type and doses.

\section{Material and Methods}

All procedures in this trial were conducted according to the ethical committee in animal experimentation of the Universidade Federal de Minas Gerais (188/2007 CETEA/ UFMG). All experimental work was performed on a commercial dairy farm in Minas Gerais state from August 2007 to July 2008.

Forty nonpregnant Holstein-Friesian cows, which had previously failed in getting pregnant, were used in this study. The cows had average body weight $727 \mathrm{~kg}$, average body condition score 4.5 and they showed an average milk production 9,200 kg in the previous lactation. Cows were distributed in a complete randomized split-plot design and assigned to two groups with 20 cows each. The first treatment day was considered to be the first bSTr application and the first milking routine day after treatment was considered as the beginning of lactation. The protocol for group 1 was the following: day 1, 8 and 21 and every 14 days, bSTr, Lactotropin ${ }^{\circledR}$ Elanco $(500 \mathrm{mg})$; from days 2 to 8 , estradiol cypionate $\left(0.075 \mathrm{mg} / \mathrm{kg} \mathrm{BW}\right.$, E.C.P. ${ }^{\circledR}$ Pfizer $)$ and acetate of medroxi progesterone $(0.25 \mathrm{mg} / \mathrm{kg} \mathrm{BW})$; from days 9 to 15 , estradiol cypionate $(0.037 \mathrm{mg} / \mathrm{kg} \mathrm{BW})$; day 19, prostaglandin F2 $\alpha$ (0.530 mg, Lutalyse ${ }^{\circledR}$ Pfizer) and from days 19 to 21, isoflupredone acetate (Predef ${ }^{\circledR}$, Pfizer) $(0.05 \mathrm{mg} / \mathrm{kg} \mathrm{BW})$. Protocol for group 2 was the following: day 1, 8, 21 and every 14 days, bSTr (Lactotropin ${ }^{\circledR}$ Elanco) (500 mg); from days 2 to 15 , estradiol benzoate $(0.071 \mathrm{mg} /$ $\mathrm{kg} \mathrm{BW}$ ); from days 2 to 8, acetate of medroxi progesterone (0.25 mg/kg BW); day 19, prostaglandin F2 $\alpha$ (0.530 mg) and from days 19 to 21 isoflupredone acetate $(0.05 \mathrm{mg} / \mathrm{kg}$ BW). All the cows had their teats and udders massaged for five minutes from day 17 to 21 to induce prolactin release. All drugs were subcutaneously applied, except isoflupredone acetate, which was intramuscularly applied. During the experimental period, all cows were housed in a loose housing system and they were fed according to their maintenance requirements (dry cows) (NRC, 2001).

Milking began on the $22^{\text {nd }}$ day of induction and at this time animals were transferred to a free stall barn. After beginning of lactation, all animals received a dose of $500 \mathrm{mg}$ of bSTr (Lactotropin ${ }^{\circledR}$ Elanco) every 14 days. During the first 30 days of lactation, four milking routines were performed followed by 3 milking routines during the rest of lactation. All milk produced was discarded during the first 21 days of lactation. Milk production was measured every fortnight and it was corrected for 3.5 fat (3.5\% FCM) according to Gravet (1987). On the same days, milk samples were collected and refrigerated at $4^{\circ} \mathrm{C}$ until analysis of milk composition (fat, protein and lactose contents) and somatic 
cell count (SCC) by infrared analysis (Bentley Instruments, Chaska, USA) at the Laboratório de Qualidade do Leite da Escola de Veterinária da UFMG.

All animals were fed in order to achieve a 24-L /day milk production during the first 30 days of lactation. After this time and after each milking record, cows were relocated in different groups according to their production, as it follows: high producing cows (more than 24 liters/day), medium producing cows (from 15 to 24 liters/day) and low producing cows (less than 15 liters/day) (Table 1). All cows were fed twice at 7:00 am and 5:00 pm.

The two protocols used in this trial cost the same: US\$ 152,00. Ovarian follicular activity was examined by linear array ultrasonography ( $5 \mathrm{MHz}$ transrectal transducer, Aloka SSD-500) every 15 days after beginning of lactation. Following ultrasound scanning, animals were submitted to the reproductive management of the farm.

Data were analyzed using Genetics and Statistical Analyses System (SAEG). Milk production and composition were analyzed using a split plot design. Groups were used as a random effect and time as the repeated statement. Milk production was evaluated for 324 days. The two artificial induction of lactation protocols were tested using ANOVA and Fisher Test (5\%). Reproduction data was analyzed trough descriptive statistics. Values of $\mathrm{P}<0.05$ were considered statistically significant.

Table 1 - Formulation and chemical composition of diets offered to high, medium and low production cows

\begin{tabular}{lccc}
\hline Formulation \%DM & High & Medium & Low \\
\hline Corn silage & 6.90 & 4.80 & - \\
Sugar cane & - & 4.80 & 8.30 \\
Tifton grass & 0.40 & - & - \\
Dry oats & 0.80 & - & - \\
Corn meal & 1.32 & 0.45 & - \\
High moisture corn & 1.34 & - & - \\
Citrus pulp & 2.22 & 1.77 & 0.71 \\
Peanut meal & - & 1.46 & 1.36 \\
Soybean meal & 3.52 & 1.14 & 0.98 \\
Soybean hulls & 1.33 & 0.45 & - \\
High producing diets orts & - & 2.03 & 2.50 \\
Mineral and vitamin premix ${ }^{1}$ & 0.08 & 0.08 & 0.08 \\
Nutrient composition & & & \\
Dry matter, \% & & & \\
Crude protein, \% & 19.50 & 18.09 & 14.59 \\
Acid detergent fiber, \% & 16.70 & 14.30 & 13.30 \\
Neutral detergent fiber, \% & 21.30 & 27.20 & 30.20 \\
Ether extract, \% & 34.50 & 39.20 & 40.40 \\
Net energy lactation & 2.80 & 2.40 & 1.90 \\
(Mcal/kg) MS & 1.62 & 1.51 & 1.45 \\
Ca & & & \\
P & 0.64 & 0.50 & 0.39 \\
\hline
\end{tabular}

${ }^{1}$ Postpartum mineral and vitamin mix (per kilogram of mix: Ca - 21\%; P - 15\%; Mg - 3\%; S - 3\%; Co - 100 ppm; Cu - 3,000 ppm; I - 180 ppm; Mn - 5,000 ppm; Se - 80 ppm; Zn - 1,2000 ppm; vit. A - 1000 KIU; vit. D - 250 KIU; vit. E - 3,250 UI.

\section{Results and Discussion}

Artificial induction of lactation yielded $85 \%$ success rate, of the total number of animals, in which 16 cows were group 1 (80\%) and 18 cows were group 2 (90\%). Milk production above $9 \mathrm{~kg}$ of milk per day was considered as artificial induction success.

The success rate observed in this study was lower when compared to the one reported by Mellado et al. (2006), who observed a $100 \%$ success rate. In this particular study the hormonal doses where higher, what could have affected the success rate.

In 324 lactations days, animals from group 2 showed higher average milk production $(\mathrm{P}<0.05)$ when compared to group 1 (Table 2). Animals from group 1 showed an average milk production of $6,137 \mathrm{~kg}$ and from group 2, the average was $7,103 \mathrm{~kg}$ which corresponded to $66.7 \%$ and $77.2 \%$ of the previous lactation, respectively. The percentage related to the previous lactation observed in this study was lower when compared to the one reported by Smith \& Schanbacher (1973), which was $82 \%$.

The differences observed between the two groups is probably related to the dose and the type of estradiol used in group 2 once all drugs and doses were the same for both artificial induction of lactation protocols. Estrogen and progesterone are important in the process of final growth of mammary gland ducts as well as in the development of the lobular - alveolar structure and probably the higher dose of estradiol in group 2 caused a stronger synergism with progesterone and better lobular-alveolar development which was reflected in the higher milk production observed in this group.

Peak milk production of cows in groups 1 and 2 occurred from 104 to 145 days of induced lactation (Figure 1). During this time, animals from group 1 showed milk production from 13.9 to $39.7 \mathrm{~kg}$ milk/day while milk production of cows in

Table 2 - Average milk production and composition ( \pm SEM) of dairy cows that received two different artificial inductions of lactation protocols

\begin{tabular}{lcccc}
\hline & Group 1 & Group 2 & P & CV (\%) \\
\hline $\begin{array}{l}\text { Milk production } \\
(\mathrm{kg})\end{array}$ & $18.9 \pm 11.5 \mathrm{~B}$ & $21.9 \pm 12.0 \mathrm{~A}$ & 0.03 & 38.4 \\
Fat correct & $17.6 \pm 10.6 \mathrm{~B}$ & $20.2 \pm 12.4 \mathrm{~A}$ & 0.04 & 38.2 \\
milk 3.5\% & & & & \\
Fat \% & $3.7 \pm 1.2$ & $3.6 \pm 1.0$ & 0.98 & 28.2 \\
Protein \% & $3.3 \pm 0.5$ & $3.3 \pm 0.5$ & 0.98 & 11.6 \\
Lactose \% & $4.3 \pm 0.5$ & $4.4 \pm 0.5$ & 0.98 & 9.2 \\
Total solids \% & $12.3 \pm 1.3$ & $12.2 \pm 1.2$ & 0.98 & 9.1 \\
Somatic cell count & $384.9 \pm 781.7$ & $523.4 \pm 1092.4$ & 0.98 & 34.1 \\
\hline
\end{tabular}

Data with different letters within a column differ $(\mathrm{P}<0.05)$ by Fisher test. $\mathrm{P}$ - Probability value - ANOVA; CV - coefficient of variation. 
group 2 ranged from 14.4 to $47.7 \mathrm{~kg}$. These delayed milk production peaks were also reported by Magliaro et al. (2004) and Mellado et al. (2006).

The reasons for the variation in results amongst animals of the same group have not been cleared yet, although it has been shown that in pregnant cows, the mamogenic and lactogenic effects of gestation are in opposition to the involution stimulus, which is observed with the milk routine break. Thus, the mammary gland of dry pregnant cows suffers the renovation and cellular proliferation process during this dry period as it is reported by Capuco et al. (2003). On the other hand, in dry non pregnant cows, hormones used to artificially induce lactation could not have been suficient to induce, at the same intensity, the renovation and cellular proliferation process in all experimental animals, which could potentially explain the variation observed in milk production in this study.

Delayed peak milk production could be related to the absence of the coupling of the somatotropic axis in animals artificially induced. Holstein dairy cows show during pre and postpartum a reduction in growth hormone (GH) receptors in liver. This reduction leads to a lower production of insulin like growth factor type I (IGF-I) and as a consequence there is an absence of the negative feedback over GH. This uncoupling of the somatotropic axis leads to a fast body reserves mobilization and all nutrients are directed towards the mammary gland, resulting in a rapid increase in milk production. According to this physiological process, the artificial induced cows showed a delayed peak milk production probably due to the absence of the uncoupling-recoupling somatotropic axis effect.

Even though lactation was finished 324 days after artificial induction, 22 cows showed milk production of $18.9 \pm 9.1 \mathrm{~kg}$ milk/day at this moment. Probably, the four milking routines performed during the first 30 days of the lactation could have stimulated secretory cells, what explains the results observed in this study. The mechanisms that control the increase in milk production when routine milking frequency is increased are still not clear, but it has been suggested that an elevation in number, metabolic activity and secretory capacity of the mammary epithelial cells could be related to this effect (Stelwagen, 2001; Connor et al., 2008), as well as a higher sensitivity to lactogenic hormones (Connor et al., 2008). Another factor that could be attributed to lactation persistency is the use of bSTr every 14 days, since this hormone improves persistency by increasing cellular proliferation and reducing apoptosis rates (Capuco et al., 2003).
There was no effect of the two artificial inductions of lactation protocols on milk composition and somatic cell count (SCC) ( $>>0.05)$. The values observed in this study are in agreement with normal range values for milk quality reported in other studies.

Estrus manifestation was not observed during the experimental period. Out of the 40 initially induced cows, 6 were excluded from the trial because of low milk production (less than $9 \mathrm{~kg}$ milk/day), 2 cows died before the 90-day artificially induced lactation (not apparent causes related to the lactation induction protocols) and 3 had uterine adherences which made them unfit for reproduction.

Therefore, 29 cows left with previous reproductive failures and these animals did not show any physical disorder during rectal and ultrasound scanning. All animals showed follicular growth from 30 to 45 days of artificially induced lactation. Those follicles increased in size and they were considered as follicular cysts because they were $25 \mathrm{~mm}$ in diameter and persisted in the ovaries for at least 10 days without the presence of a corpus luteum. All animals were treated with GnRH and PGF2 $\alpha$. After follicular dynamics recovery, animals were artificially inseminated. Out of 29 cows, 12 became pregnant, which stands for $41.4 \%$ and out of those, 4 showed embryonic mortality and abortion and the other 8 had a successful pregnancy and commence of a new lactation.

The cost of the artificial induction of lactation was the same for both protocols, being group 2 the one that showed the most efficient performance, making relatively easy the decision taking of which protocol should be used. However, at the time of decision making it is worth to remember that approximately $10 \%$ of animals did not respond to artificial induction of lactation as well as the fact that milk production in this type of animals varies very much.

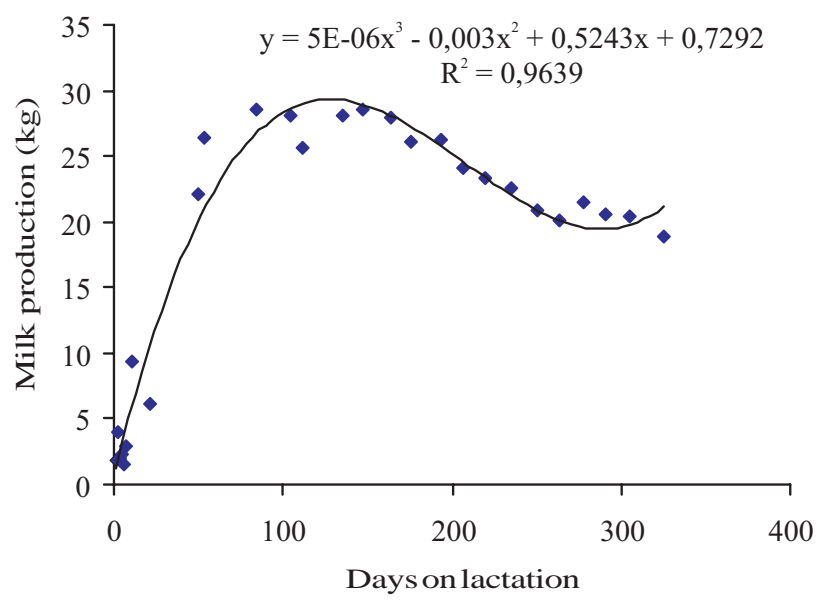

Figure 1 - Lactation curve of artificial induced cows. 


\section{Conclusions}

The two protocols used in this study are efficient in artificially inducting lactation. Group 2 protocol is the one that is more efficient, showing better results regarding to total number of animals successfully induced, average milk production per day, peak milk production and total milk production during that lactation. Milk composition is not affected by the protocols used in this study.

\section{References}

CAPUCO, A.V.; ELLIS, S.E.; HALE, S.A. et al. Lactation persistency: insights from mammary cell proliferation studies. Journal of Animal Science, v.81, p.18-31, 2003.

COLLIER, R.J.; BAUMAN, D.E.; HAYS, R.L. Milk production and reproductive performance of cows hormonally induced into lactation. Journal of Dairy Science, v.58, p.1524-1527, 1977.

CONNOR, E.E; SIFERD, S.; ELSSASSER, T.H. et al. Effects of increased milking frequency on gene expression in the bovine mammary gland. BMC Genomics, v.9, p.1-14, 2008.
GRAVET, H.O. Breeding of dairy cattle. In: Dairy cattle production. New York, Gravet: Elsevier Science, 1987. p.35-76.

JEWELL, T. Artificial induction of lactation in nonbreeder dairy cows. 2002. 47f. Master of Science (Dairy Science) - Faculty of the Virginia Polytechnic Institute, Blacksburg. MAGLIARO, A.L.; KENSINGER, R.S.; FORD, S.A. et al. Induced lactation of nonpregnant cows: profitability and response to bovine somatotropin. Journal of Dairy Science, v.87, p.3290-3297, 2004.

MELLADO, M.; NAZARRE, E.; OLIVARES, L. et al. Milk production and reproductive performance of cows induced into lactation and treated with bovine somatotropin. Animal Science, v.82, p.555-559, 2006.

NATIONAL RESEARCH COUNCIL - NRC. Nutrient requirements of dairy cattle. 7.ed. Washington, D.C: National Academy Press, 2001. 381p.

SILVA, L.A.F.; COELHO, K.O.; MACHADO, P.F. et al. Causas de descarte de vacas da raça Holandesa confinadas em uma população de 2083 bovinos (2000-2003). Ciência Animal Brasileira, v.9, p.383-389, 2004.

SMITH, K.L.; F.L. SCHANBACHER. Hormone induced lactation in the bovine I. Lactational performance following injections of $17 \beta$-estradiol and progesterone. Journal Dairy Science, v.56, p.738-743, 1973.

STELWAGEN, K. Effect of milking frequency on mammary functioning and shape of the lactation curve. Journal Dairy Science, v.84 (Suppl. E), p.E204-E211, 2001.

UNIVERSIDADE FEDERAL DE VIÇOSA - UFV. Sistema de análises estatísticas e genéticas - SAEG. Versão 8.0. Viçosa, MG, 2000. 